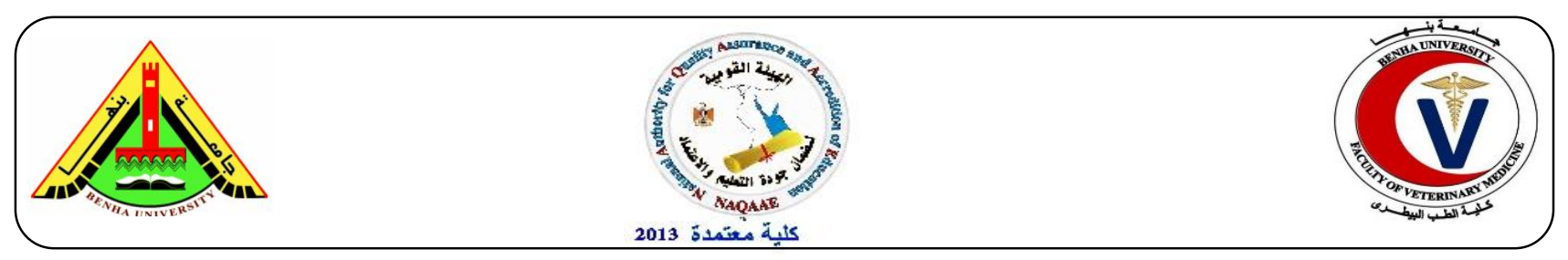

\title{
Separation the Potent Antibacterial Peptides from Hydrolyzed Hen Egg Lysozyme
}

\author{
Dina, A. Awad ${ }^{1}$, Hamdi, A. Mohammed ${ }^{1}$, Adham, M. Abdou' ${ }^{1}$ Sobhy, A. El Sohaimy ${ }^{2}$ \\ ${ }^{l}$ Department of Food Hygiene, Faculty of Veterinary Medicine, Benha University, Egypt. \\ ${ }^{2}$ Food Technology ARID Land Research Institute, City of Scientific Research and Technology Application- \\ Borg Elarb-Alexanderia.
}

\section{A B S T R A C T}

Due to dietary proteins exert many functionalities by means of biologically active peptides which are inactive within their parent proteins. So out target was to separate these biological active peptides from their parent proteins using a simple cheap method for fractionation like ammonium sulfate precipitation after enzymatic hydrolysis. Egg is a natural food which provides numerous nutritional and biologically active substances. Egg white is the richest natural source of proteins. In our study we make hydrolysis for hen egg white lysozyme using peptic digestion then the hydrolysates were separated by ammonium sulfate precipitation and determine the antibacterial activity of the separated peptides against different bacterial strains comparing with native lysozyme using liquid broth with studying the molecular structure by using electrophoresis. Our results declared that, the fraction $2 \%$ was the most potent antibacterial activity then followed by LzP3. On the other hand, fraction $4 \%$ was similar in the antibacterial activity with native lysozyme. Electrophoresis showed similar molecular structure between fraction $4 \%$ and native lysozyme and between LzP3 and fraction $4 \%$ but with high intensity for the low molecular weight peptides which was responsible for the potent antibacterial activity. On conclusion, low molecular weight peptides produced from lysozyme hydrolysates with strong antibacterial activity can be applied for food biopreservation or for therapeutic uses in the future.

Keywords: Lysozyme, Ammonium sulfate precipitation, antibacterial activity, peptic hydrolysis, Egg.

(BVMJ-35(2): 142-149, 2018)

\section{INTRODUCTION}

The importance of proteins in the diet has been increasingly acknowledged over the last two decades. Recently it has been recognized that dietary proteins exert many functionalities in vivo by means of biologically active peptides which are inactive within the sequence of the parent protein, such peptides can be released by digestive enzymes during digestion (Chakrabarti et al., 2014).

Egg is a natural food which provides numerous nutritional and biologically active substances, Egg white is the richest natural source of proteins. Three major proteins, like lysozyme, ovotransferrin and ovalbumin are of particular significance. One of the natural antimicrobial 
proteins, widely studied, is hen egg white lysozyme which is small enzyme (129 amino acid residues) commonly known for its antimicrobial activity against Gram positive bacteria, due to its muramidase activity (Masschalck and Michiels, 2003). The most common way to produce bioactive peptide is through enzymatic hydrolysis of whole protein molecules. Many of the known bioactive peptides have been produced using gastrointestinal enzymes, usually pepsin and trypsin (FitzGerald et al., 2004).

Over the last years, various techniques have been developed to separate protein after its hydrolysis. Ion exchange chromatography is among the most widely used methods, but has limitations for scale up preparation because of the costs involved, and separation speed and yield issues (Awadé, et al., 1994; Croguennec, et al., 2001).

Other simple methods used for purification can be developed like ammonium sulfate precipitation to yield an enriched bioactive peptide preparation. So the main aim of this study was to make enzymatic hydrolysis of lysozyme and separate its peptides using ammonium sulfate precipitation then determine the antibacterial activity of these peptides produced compared with the native lysozyme and lysozyme hydrolysate.

\section{Materials and methods}

\subsection{Materials:}

Native lysozyme chloride powder ( $\mathrm{pH}$ 3.6) isolated from hen egg white, its activity 22400 U/mg was obtained from Dalian Greensnow Egg Products Development Co., LTD., China. Pepsin crystalline $(10000 \mathrm{U} / \mathrm{mg}$ obtained from porcine stomach) obtained from Nacalai Tesque, INC. Kyoto, Japan. Micrococcus lysodeikticus and Trypticase soy broth (TSB) were purchased from Sigma Chemical Co., St. Louis, MO.USA.

\subsection{Examined bacterial strains:}

The bacterial strains E.coli (IFO 3301) and Staphylococcus aureus (NBRC 12462), were obtained from Animal Research Institute, Doki, Giza, Egypt. All strains were maintained in TSB with $10 \%$ glycerol at $20^{\circ} \mathrm{C}$.

2.3. Enzymatic hydrolysis of native lysozyme: Enzymatic hydrolysis occurred according to Carrillo, et al., (2014) with some modification. About 80 milliliter of lysozyme solution $(0.1 \mathrm{~g} / 1 \mathrm{ml}$ in sterile distilled water) was mixed with $20 \mathrm{ml}$ of pepsin solution $(0.01 \mathrm{~g} / \mathrm{ml}$ buffer $\mathrm{pH}$ 2.0) to obtain an enzyme to-substrate ratio of 1:4 (wt/wt). This mixture was incubated with stirring at $37^{\circ} \mathrm{C}$ for $2 \mathrm{hr}$ after adjustment $\mathrm{pH}$ 3.0. The reaction was quashed by heating at $80^{\circ} \mathrm{C}$ for $10 \mathrm{~min}$. Followed by direct cooling to produce lysozyme peptides (LzP3) kept at $4^{\circ} \mathrm{C}$ till use.

\subsection{Measurement of Muramidase activity:}

The lytic activity of the samples were measured against Micrococcus lysodeikticus cells according to a turbidimetric method, previously reported (Ibrahim, et al., 1996) based on the decrease in turbidity of $1.9 \mathrm{ml}$ cell suspension $(170 \mu \mathrm{g}$ dry cells $\mathrm{ml}-1)$ in $50 \mathrm{mM}$ potassium phosphate buffer ( $\mathrm{pH}$ 6.0) following the addition of $100 \mu \mathrm{l}$ portion of the samples solutions after equilibration to achieve constant absorbance. The decrease in absorbance at $450 \mathrm{~nm}$ was monitored using spectrophotometer. The enzymatic activity is expressed as a percentage relative to native lysozyme.

\subsection{Fractionation of $L z P$ using ammonium} sulfate:

Lysozyme hydrolysates were treated and fractioned with different levels of ammonium sulfate using a two-step protocol (scheme1). In the first step, fully saturated ammonium sulfate solution (767 g/L, pH 7.4) was added at two different levels $(2,4 \%)$ slowly to the LzP3 sample while gently stirring for $30 \mathrm{~min}$ in cooling temperature. The precipitate was then removed after centrifugation $(10000 \mathrm{~g}, 10 \mathrm{~min})$ and the supernatant was collected. The second 
step consists of an addition of fully saturated ammonium sulphate solution to the supernatant till a final concentration of $4 \%$. The precipitate was collected after centrifugation (10000g for $30 \mathrm{~min}$ ) and supernatant removed. The pellet was suspended with 2 volumes buffer $\mathrm{pH} 2.5$. Then desalted by using dialysis bag overnight at cooling temperature with 4 time exchange (Jovanović, et al., 2015).

\subsection{Determination Protein concentration:}

Protein content was determined by Bradford method (Bradford, 1976) using dye reagent at $595 \mathrm{~nm}$. Using Bovine serum albumin BSA $(0.2-1.4 \mathrm{mg} / \mathrm{mL})$ as a standard curve to calculate the protein content.

\subsection{Antimicrobial Activity assay:}

Native lysozyme, LzP3 and the separated fractions were prepared to give a final concentration of $100 \mu \mathrm{g} / \mathrm{ml}$. As previously described (Ibrahim, et al., 2001), aliquots (400 $\mu \mathrm{l})$ of trypticase soy broth were mixed with $200 \mu \mathrm{l}$ of the bacterial suspension (adjusted to a final concentration of $3 \mathrm{log} \mathrm{cfu} / \mathrm{ml}$ ). Using a representative microorganism for gram negative bacteria as E.coli and for gram positive bacteria as Staphylococcus aureus then $200 \mu \mathrm{l}$ of the samples were prepared to give a final concentration $50,25,5 \mu \mathrm{g} / \mathrm{ml}$. A positive control was prepared without the addition of protein and negative control without addition of pathogen. The suspensions were incubated for $2 \mathrm{hr}$ at $37^{\circ} \mathrm{c}$, serially diluted in buffer $\mathrm{pH} 7.0$ and plated on trypticase soy agar. Colony-forming units were obtained after incubation of the plates at the specified temperature $30^{\circ} \mathrm{C}$ for $48 \mathrm{~h}$. All assays were performed in triplicates and the results are the means of three independent experiments.

\subsection{Molecular weight measurement:}

The sodium dodecyl sulfatepolyacrylamide gel electrophoresis SDSPAGE was conducted under reduced conditions using a Mini vertical electrophoresis gel (Hoefer) as described by
Laemmli (1970). To examine the purity of the lysozyme preparations and to obtain a molecular mass, $15 \%$ acrylamide were used to resolve the peptides. Samples were diluted 1:4 (v:v) in $0.5 \mathrm{M}$ Tris- $\mathrm{HCl}$ buffer, $\mathrm{pH} 6.8$, containing $1.6 \%$ SDS, $8 \%$ glycerol, $4 \% 2-\beta-$ mercaptoethanol and $0.002 \%$ bromophenol blue heated at $95^{\circ} \mathrm{C}$ for $10 \mathrm{~min}$. Ten microliters (50 $\mu \mathrm{g}$ as conc.) of each sample was loaded onto each well in Tris glycine SDSpolyacrylamide gels with 5\% stacking gel were prepared and Coomassie Brilliant Blue R-250 gel pictures were taken after destaining. Electrophoresis was carried out at 150 V.A broad range molecular marker (Bio-Rad) was used as the marker.

\subsection{Statistical analysis:}

Statistical comparisons were made by using one-way analysis of variance (ANOVA). The results were considered significantly different with $\mathrm{P}<0.05$ as described by Clarke and Kempson (1997).

\section{RESULTS}

\subsection{Antibacterial activity of native lysozyme} compared with its peptic digests and separated fractions:

We had examined the antibacterial activity of native lysozyme comparing with its peptic hydrolysates and the isolated fractions by ammonium sulfate against a gram-positive (Staphylococcus aureus) and a gram-negative bacterial strains (E.coli) as a function of increasing protein concentration when incubated with tested bacteria for $2 \mathrm{hr}$. It is clear in (table1) that native lysozyme had the lowest antibacterial activity against E.coli while the fraction $2 \%$ had the highest antibacterial activity followed by LzP3 in comparing with positive control. Their antibacterial effect were in a dose-dependent manner as at concentration $25 \mu \mathrm{g} / \mathrm{ml}$ we found the fraction $2 \%$ caused complete bacterial inhibition. On the other side, the fraction $4 \%$ 
caused similar antibacterial activity for native lysozyme but to some extent more potent. The same trend for staphylococcus aureus where fraction $2 \%$ gave complete bacterial inhibition at the lowest concentration used $(5 \mu \mathrm{g} / \mathrm{ml})$ followed by LzP3. In the same time, we found fraction $4 \%$ behaved in the same manner like native lysozyme in a dose dependent manner while, peptic hydrolysate (LzP3) LzP3 produced complete bacterial inhibition at higher concentration $25 \mu \mathrm{g} / \mathrm{ml}$.

\subsection{Lytic activity of peptic hydrolysates} comparing with native lysozyme and separated fractions:

Figure 1 showed the changes in lytic activity\% of the produced hydrolysates comparing with native lysozyme and the separated fractions. Where the fraction $2 \%$ had the lowest lytic activity about $5 \%$ then followed by fraction $4 \%$ and LzP3 $11 \%$ and $15 \%$ respectively comparing with native lysozyme which reached $100 \%$ lytic activity.

\subsection{Molecular characters of the produced fractions:}

Figure 2 showed the reducing electrophoretic gel we found native lysozyme at the range 14.5KDa. By peptic hydrolysis LzP3 it produced smaller peptides below $6.5 \mathrm{KDa}$ but, with low intensity. By more separation using ammonium sulfate fraction $2 \%$ contain the same structure of LzP3 but, with high intensity of band below $6.5 \mathrm{KDa}$. While fraction $4 \%$ contain the common structure of the native lysozyme and the low molecular weight bands but faint intensity.

Table 1: Comparison the antibacterial activity between native lysozyme, LzP3 and the separated fractions using ammonium sulfate against Escherichia coli. The assays were performed using liquid broth method where test bacteria incubated with protein samples in different concentrations for $2 \mathrm{~h}$ then plated for $18 \mathrm{~h}$ in presence of control where bacterial culture with a mid-logarithmic phase incubated with sterile milli $\mathrm{Q}$ water instead of test protein. The assay repeated 3 times.

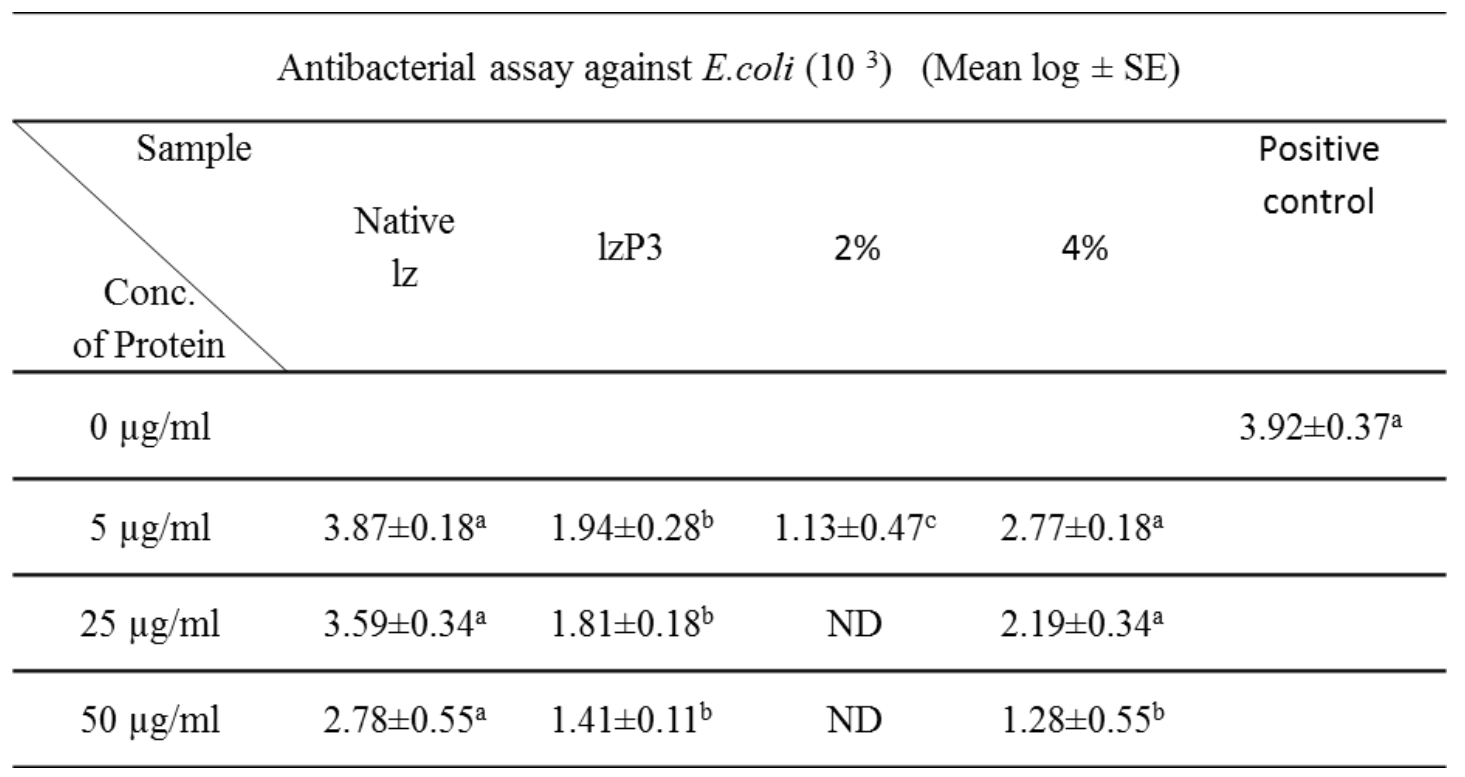

Means within the same row having different superscripts are significantly different $(\mathrm{p} \leq 0.05)$.

ND:not detected 
Table 2: Comparison the antibacterial activity between native lysozyme, LzP3 and the separated fractions using ammonium sulfate against Staphylococcus aureus. The assays were performed using liquid broth method where test bacteria incubated with protein samples in different concentrations for $2 \mathrm{~h}$ then plated for $18 \mathrm{~h}$ in presence of control where bacterial culture with a mid-logarithmic phase incubated with sterile milli $\mathrm{Q}$ water instead of test protein. The assay repeated 3 times.

\begin{tabular}{cccccc}
\hline Antibacterial assay against staphylococcus aureus $\left(10^{3}\right)$ & $($ Mean $\log \pm \mathrm{SE})$ & \\
\hline $\begin{array}{c}\text { Sample } \\
\text { Native } \\
\begin{array}{c}\text { Conc. } \\
\text { of Protein. }\end{array}\end{array}$ & $1 \mathrm{zP} 3$ & $2 \%$ & $4 \%$ & $\begin{array}{c}\text { Positive } \\
\text { control }\end{array}$ \\
\hline $0 \mu \mathrm{g} / \mathrm{ml}$ & & & & \\
\hline $5 \mu \mathrm{g} / \mathrm{ml}$ & $2.97 \pm 0.58^{\mathrm{a}}$ & $1.64 \pm 0.68^{\mathrm{b}}$ & $\mathrm{ND}$ & $2.57 \pm 0.48^{\mathrm{a}}$ & \\
\hline $25 \mu \mathrm{g} / \mathrm{ml}$ & $2.29 \pm 0.64^{\mathrm{a}}$ & $1.01 \pm 0.78^{\mathrm{b}}$ & $\mathrm{ND}$ & $2.19 \pm 0.84^{\mathrm{a}}$ & \\
\hline $50 \mu \mathrm{g} / \mathrm{ml}$ & $2.18 \pm 0.15^{\mathrm{a}}$ & $\mathrm{ND}$ & $\mathrm{ND}$ & $1.28 \pm 0.65^{\mathrm{b}}$ & \\
\hline
\end{tabular}

Means within the same row having different superscripts are significantly different $(\mathrm{p} \leq 0.05)$.

ND:not detected

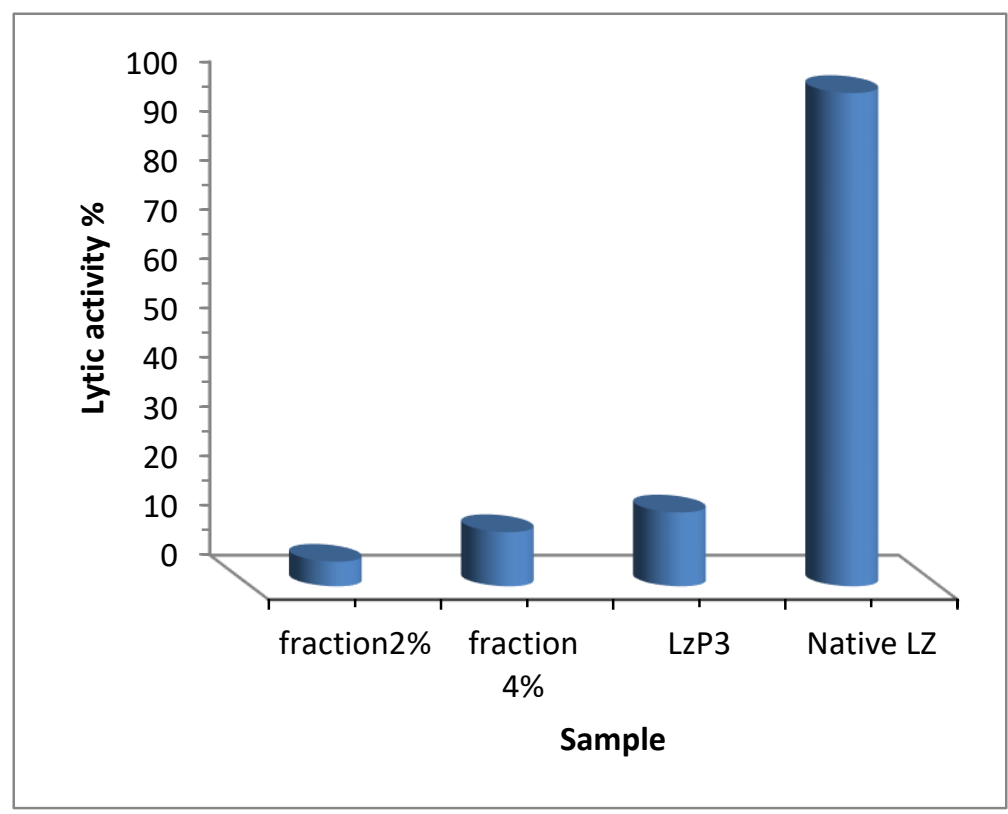

Fig.1. Comparison the lytic activity between native lysozyme, LzP3 and the separated fractions using ammonium sulfate. Aliquots $(100 \mu \mathrm{l})$ containing test protein in $50 \mathrm{mM}$ potaasium phosphate buffer, $\mathrm{pH} 6.5$ were added to $1.9 \mathrm{ml}$ of M. lysodeikticus cell suspensions as a substrate in the same buffer and was monitored at the absorbance $(450 \mathrm{~nm})$. The activity is expressed as the rate of decrease in absorbance per min of the initial velocity of reaction. 


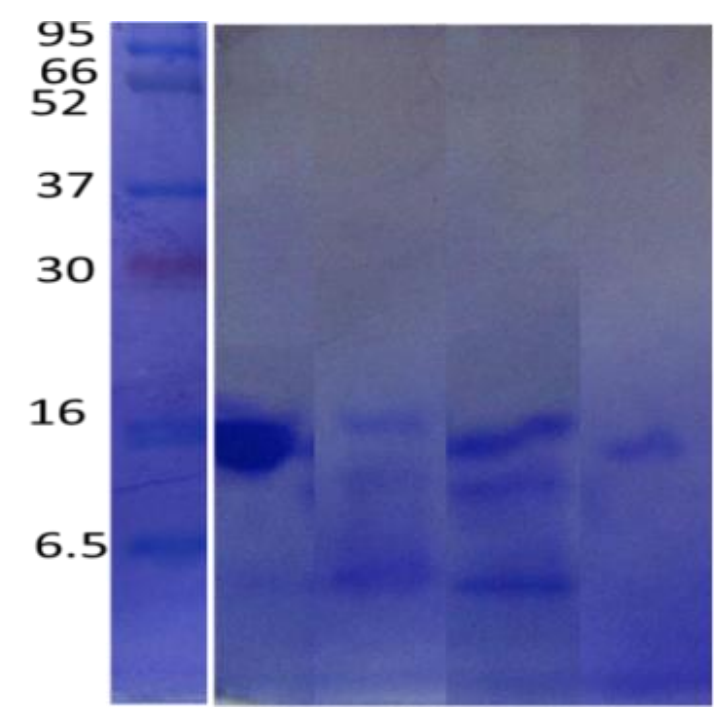

Fig.2. Electrophoretic patterns of native lysozyme, LzP3 and the separated fractions using ammonium sulfate on $15 \%$ reducing polyacrylamide gels using SDS and 2-mercaptoethanol (2-ME). SDS-PAGE stained with Coomassie Blue R250. Mr, Biorad marker.

\section{DISCUSSION}

Egg white is considered as a rich source of high quality proteins with various bioactive peptide fractions. Enzymatic hydrolysis of proteins can be used to release bioactive fractions using different enzymes depending on the enzyme's site of activity on a protein (Nimalaratne, et al., 2015). Various strategies had been used to increase the antimicrobial activity of lysozyme against Gram-negative bacteria by inserting hydrophobic moiety or lipophilization and conjugation with other substances like EDTA (Ibrahim, et al., 2002). Our study depend on enzymatic hydrolysis for hen egg white lysozyme then separation the most active fraction. Accordingly, there is a need to develop efficient, simple and cost-effective methodologies for isolation and purification of egg proteins and their peptides. One of the classical methods of protein fractionation is ammonium sulfate precipitation (king, 1972).

The above results clearly indicated that the gradient solubilization procedure for ammonium sulfate fractionation of proteins according to scheme 1 . Our study was focused on the changes in the antibacterial activity of native lysozyme, after peptic hydrolysis then separation using ammonium sulfate. Peptic hydrolysis of native LZ acquired potent antibacterial activity this due to some peptide is usually inactive when exists as a part of the parent protein but can be become more active when released during hydrolysis. It was observed that the conditions of producing LzP3 were similar to gastric digestions. On general lysozyme was not active against gram negative bacteria but LzP3 more potent against gram negative bacteria where lysozyme is effective against Gram-positive bacteria only (Ibrahim, et al., 2002). By more fractionation we found that fraction $2 \%$ produce complete bacterial growth inhibition which acquired the least lytic activity. This was due the $2 \%$ fraction contain high concentration from the low molecular weight peptides comparing with LzP3 that was responsible for the potent antibacterial activity according to fig.2. While the fraction $4 \%$ was similar for the native 
lysozyme in the molecular structure so, gave similar antibacterial activity.

Our results were agreed with Ibrahim et al. (2001) whom found antimicrobial peptides (internal peptide residues 98-112) within lysozyme that was effective against gramnegative bacteria, without lytic activity.

Lysozyme acts by lysing the cell wall of certain gram-positive bacteria by splitting $b$ (1-4) linkages between $\mathrm{N}$-acetylmuramic acid and $\mathrm{N}$-acetylglucosamine of the peptidoglycan of bacterial cell walls (Nakamura et al., 1997). By contrast, it has limited bactericidal effect against gram-negative bacteria. As the peptidoglycan layer, being the substrate of lysozyme, is covered another outer membrane consisting of lipoproteins, lipopolysaccharides (LPS) and some hydrophobic peptides. The outer membrane serves as a barrier to the access of enzyme to its site of action. It is most probable that lysozyme can be entrapped in the outer membrane by LPS of Gram-negative bacteria and inactivated (Ibrahim et al., 1993).

\section{Conclusion}

Salt precipitation fractionation by ammonium sulfate is a very powerful tool to purify proteins by precipitation. Low molecular weight peptides produced from the gastric digestion of native lysozyme which produce more potent antibacterial activity against gram negative bacteria and also become more potent against gram positive bacteria without lytic activity even at low concentrations $(5 \mu \mathrm{g} / \mathrm{ml})$. Although lysozyme had the highest lytic activity but not show any antibacterial activity against gram negative bacteria. So biological active peptides can be produced from lysozyme can be used for food preservation due to its antibacterial action and may be used for therapeutic purposes in the future.

\section{REFERENCES}

Awadé, C.; Moreau, S.; Mollé, D.; Brulé, G. and Maubois, J. L. (1994): Two-step chromatographic procedure for the purification of hen egg white ovomucin, lysozyme, ovotransferrin and ovalbumin and characterization of purified proteins. Journal of Chromatography. A, 677(2), 279-88.

Bradford, M.M. (1976): A rapid and sensitive method for the quantification of microgram quantities of protein utilizing the principle of protein-dye binding. Anal Biochem 72(2):248-254.

Carrillo, W.; García-ruiz, A.; Recio, I. and Moreno-arribas, M. V. (2014): Antibacterial Activity of Hen Egg White Lysozyme Modified by Heat and Enzymatic Treatments against Oenological Lactic Acid Bacteria and Acetic Acid Bacteria. Journal of Food Protection, 77(10), 1732-1739.

Chakrabarti, S.; Jahandideh, F. and Wu, J. (2014): Food-derived bioactive peptides on inflammation and oxidative stress. BioMed Research International, 2013, $1-8$.

Clarke, G.M. and Kempson, R.E. (1997): Introduction to the design and analysis of experiments. Arnold, a member of the Holder Headline Group. 1st ed., London, UK.

Croguennec, T.; Nau, F.; Pezennec, S.; Piot, M. and Brule. G. (2001): Two-step chromatographic procedure for the preparation of hen egg white ovotransferrin. Eur. Food Res. Technol. 212:296-301

FitzGerald, R. J.; Murray, B. A. and Walsh, D. J. (2004): Hypotensive peptides from milk proteins. Journal of Nutrition, 134, 980S-988S. 
Ibrahim, H.R.; Thomas, U. and Pellegrini, A. (2001): A Helix-Loop-Helix Peptide at the Upper Lip of the Active Site Cleft of Lysozyme Confers Potent Antimicrobial Activity with Membrane Permeabilization Action. The Journal OF Biological Chemistry Vol. 276, No. 47, Issue of November 23, pp. 4376743774.

Ibrahim, H.R.; Aoki, T. and Pellegrni, A. (2002): Strategies for new antimicrobial proteins and peptides: Lysozyme and aprotinin as a model molecules. Current Pharmaceutical Design 8: 671-693.

Ibrahim, H.R.; Higashiguchi, S.; Juneja, L. R.; Kim, M. and Yamamoto, T. (1996): A Structural Phase of Heat-Denatured Lysozyme with Novel Antimicrobial Action. Journal of Agricultural and Food Chemistry, 44(6), 1416-1423.

Ibrahim, H.R.; Kobayasi, K. and Kato, A. (1993): Length of hydrocarbon chain and antimicrobial action to Gramnegative bacteria of fatty acylated lysozyme. J Agr Food Chem, 41(7), $1164-1168$.

Jovanovic, M.; Rooney, M. S.; Mertins, P.; Przybylski, D.; Chevrier, N.; Satija, R. and Regev, A. (2015):Dynamic profiling of the protein life cycle in response to pathogens. Science, 347(6226), 1-12.

King, T. P. (1972): Separation of Proteins by Ammonium Sulfate Gradient Solubilization. Biochemistry, 11(3), 367-371.

Laemmli, U.K. (1970): Cleavage of structural proteins during the assembly of the head of bacteriophage T4. Nature, 227(5259), 680-685.
Masschalck, B. and Michiels, C. W. (2003): Antimicrobial properties of lysozyme in relation to foodborne vegetative bacteria. Critical Reviews in Microbiology, 29(3), 191-214.

Nakamura, N.K.; Furukawa, N.; Matsuoka, M.; Takahashi T. and Yamanaka, Y. (1997): Enzyme activity of lysozymedextran complex prepared by highpressure treatment. Food Sci. Tech. Int. 3, 235-238.

Nimalaratne, C.; Bandara, N. and $\mathrm{Wu}, \mathrm{J}$. (2015): Purification and characterization of antioxidant peptides from enzymatically hydrolyzed chicken egg white. Food Chemistry, 188, 467472. 